Article

\title{
A New Active Substance Derived from Lyzed Willaertia magna C2c Maky Cells to Fight Grapevine Downy Mildew
}

\author{
Sandrine Demanèche *D, Laurène Mirabel, Olivier Abbe, Jean-Baptiste Eberst and \\ Jean-Luc Souche \\ R\&D Department, Amoéba, 69680 Chassieu, France; laurene.mirabel@amoeba-biocide.com (L.M.); \\ olivier.abbe@amoeba-biocide.com (O.A.); jean-baptiste.eberst@amoeba-biocide.com (J.-B.E.); \\ jean-luc.souche@amoeba-biocide.com (J.-L.S.) \\ * Correspondence: sandrine.demaneche@amoeba-biocide.com; Tel.: +33-426-691-600
}

Received: 10 July 2020; Accepted: 10 August 2020; Published: 11 August 2020

\begin{abstract}
Downy mildew of grapevine is one of the most destructive grapevine diseases worldwide. Nowadays, downy mildew control relies almost exclusively on the use of chemical pesticides, including copper products, which are efficient but controversial due to their environmental toxicity. Natural plant protection products have become important solutions in the quest for the sustainable production of food and pest management. However, most biocontrol agents currently on the market, such as biofungicides or elicitors, have a limited efficacy; thus, they cannot replace chemical compounds in full. Our innovation is a natural active substance, which is a lysate of the amoeba Willaertia magna C2c Maky. This active substance is not only able to elicit grapevine defenses, but it also demonstrates direct fungicidal activity against Plasmopara viticola. The efficacy of this new natural substance was demonstrated both in a greenhouse and in a field. The amoeba lysate provided up to $77 \%$ protection to grapevine bunches in the field in a natural and safe way.
\end{abstract}

Keywords: Plasmopara viticola; biofungicide; Willaertia magna C2c Maky; downy mildew; grapevine

\section{Introduction}

The grapevine industry, which represented 7.4 million hectares of crops worldwide in 2018 and is mainly spread over five countries (Spain, China, France, Italy, and Turkey) [1], is highly affected by downy mildew of grapevine, one of the most destructive grapevine diseases worldwide [2]. Indeed, it can decrease the crop yield by over $30 \%$, and can also have an impact on fruit and wine quality [3]. The downy mildew of grapevine, probably introduced into Europe in the 1870s from infected American grafts used to replant the French vineyards destroyed by Phylloxera, is caused by Plasmopara viticola [4]. Described for the first time in 1834 from north-eastern United States vine samples and finally identified as $P$. viticola in 1888 [4], this micoorganism is an obligate biotrophic oomycete that affects every green and young grapevine organ [5]. During the winter season, the pathogen P. viticola is mainly preserved in oospore shape in soils, waiting for spring. When the temperatures reach more than $11^{\circ} \mathrm{C}$ and when the rain falls, oospores germinate and zoospores are produced, which contaminate young grapevine organs [6].

Currently, the vine cultivars mainly used in Europe are not resistant to this disease. Although some resistant varieties exist, they have not been able to find a place in the market until now [7]. Currently, downy mildew control relies almost exclusively on the use of chemical pesticides, including copper products, which are efficient but controversial due to their environmental and human toxicity $[4,7]$. Although some curative fungicides exist, resistance toward these quickly emerged. Current strategies 
to control grapevine downy mildew are based on the use of preventive fungicide treatments, among these, copper and mancozeb are still widely used. Control of grapevine downy mildew can also be achieved by mixing or alternating products containing active substances with different mode of actions to increase disease control and reduce the risk of resistance from the beginning of the period during which plants are susceptible to infection [4]. A total number of 10 annual applications, or even more on rainy years, is a very common practice in some regions, such as the southwest of France (Bordeaux). Some studies have shown that copper in soil accumulates after several applications, increasing copper availability, which can become excessive and cause grapevine damage, such as physiological changes and reduced photosynthesis rates and plant growth [8].

Current European environmental plans require reducing chemical pesticides in crop treatments and replacing them with natural substances [9]. Moreover, by the end of 2019, the European Commission renewed the authorization of copper for only seven years and limited its use to an average of $4 \mathrm{~kg}$ per hectare per year. It is possible that it can be withdrawn after 2026, as is already the case in Denmark and the Netherlands. Moreover, Mancozeb, a key standard fungicide on both grapes and potatoes, could also be banned as early as 2021. According to this European trend, and due to the need for other solutions for organic crops, biological alternatives are in high demand.

In this context, Amoéba, a young and innovative company, has developed a natural product based on the amoeba Willaertia magna C2c Maky to control downy mildew of grapevine. W. magna C2c Maky, a thermophilic free-living amoebae (FLA) belonging at the Vahlkampfiidae family [10], was isolated from the water of a thermal swimming pool in 1988. The lack of pathogenicity of this amoeba was demonstrated by culture and confirmed by omic analyses [11,12]. FLA are ubiquitous protozoa that inhabit common aquatic environments $[13,14]$. FLA are predatory and consume bacteria for their growth [15-17]. All published papers on FLA deal with the living form of the amoebas and their phagocytic activities. For the first time, we report a potential application of the dead form of W. magna C2c Maky (lysate) in the domain of plant protection products. The product developed by Amoéba is derived from the dead form of amoeba, lysed by high-pressure homogenization. This is the first report to our knowledge of the development of a fungicide product based on a free-living amoeba. This paper highlights the innocuity and the efficacy of the lysate of W. magna C2c Maky against the downy mildew of grapevine, both in a greenhouse and in a field, and presents its dual mode of action.

\section{Results}

\subsection{Elicitor Property}

\subsubsection{Comparative Analysis of Grapevine Gene Defense Induction}

To determine, in controlled conditions, whether W. magna C2c Maky lysate has properties to induce plant defense genes in grapevine plants, the $\mathrm{qPFD}^{\circledR}$ system based on 28 marker genes was used [18]. The genes were selected as being representative of the main defense pathways in plants, from the genes involved in parietal modification to those in the signaling pathways (i.e., salicylic acid, jasmonic acid, and ethylene).

In this experiment, the internal check inducers ChitoOlygoSaccharides and OligoGAlacturonide (COS-OGA) [19] showed a low to moderate induction capacity of pathogen-related (PR) protein genes. It also induced the glutathione S-transferase (GST) gene at a high level, especially at the sampling date of two days after treatment (D2) (Figure 1a). Overall, the gene induction levels were higher at D2 than at D3 (three days after treatment) for the check inducer. The amoeba lysate, at a dose of $3 \mathrm{~g} / \mathrm{L}$, induced mainly PR protein genes at the sampling date D3, whereas at a dose of $1 \mathrm{~g} / \mathrm{L}$, it induced some PR protein genes, mainly at the sampling date D2 (Figure 1a). The polyphenol oxidase (PPO) gene was moderately induced at a dose of $3 \mathrm{~g} / \mathrm{L}$ and not induced at $1 \mathrm{~g} / \mathrm{L}$, whereas the (E,E)-alpha-farnesene synthase (far) gene was highly induced at D2 by the lysate at $1 \mathrm{~g} / \mathrm{L}$ and moderately induced at D3 by the lysate at $3 \mathrm{~g} / \mathrm{L}$. 
Analysis of the cumulation of inductions of the 28 genes confirmed that the internal check inducer had a moderate induction effect, higher at the sampling date D2 than at D3, with values around 18 and 10 , respectively (Figure $1 \mathrm{~b}$ ). The amoeba lysate, at a dose of $3 \mathrm{~g} / \mathrm{L}$, had a low induction effect at D2 $(<10)$, lower than the internal check inducer. At D3, it showed a moderate induction effect $(>10)$, slightly higher than the internal check inducer at the same date. At a dose of $1 \mathrm{~g} / \mathrm{L}$, it had globally a low induction effect at D2 $(<10)$ and did not show any significant induction capacity at D3.

\begin{tabular}{|c|c|c|c|c|c|c|c|c|c|c|c|c|c|c|c|c|c|c|c|c|c|c|c|c|c|c|c|c|c|}
\hline \multirow[b]{2}{*}{ TREATMENTS } & \multirow[b]{2}{*}{ Day } & \multicolumn{4}{|c|}{ Pathogen Related ( } & \multicolumn{3}{|c|}{ PR) PROTEINS } & \multicolumn{5}{|c|}{ Phenylpropanoids } & \multicolumn{3}{|c|}{ Isopropenoids } & \multirow{2}{*}{\begin{tabular}{|c|} 
Cysteins \\
CSL \\
\end{tabular}} & \multicolumn{3}{|c|}{ Oxidative stress } & \multicolumn{3}{|c|}{ Parietal modif } & \multicolumn{2}{|c|}{ SA } & \multicolumn{2}{|c|}{$J A$} & \multicolumn{2}{|c|}{ ET } \\
\hline & & PR1 & $P R 2$ & PR4 & PR5 & PR8 & PR14 & PR15 & $\mathrm{PAL}$ & CHS & DFR & ANS & PPO & HMGR & FPPS & FAR & & APOX & GST & $\mathrm{POX}$ & CALS & PECT & CAD & EDS1 & WRKY & LOX2 & JAR & $\mathrm{ACCO}$ & EIN3 \\
\hline WATER & D2 & 1 & 1 & 1 & 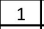 & 1 & 1 & 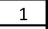 & 1 & 1 & 1 & 1 & 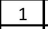 & 1 & 1 & 1 & 1 & 1 & 1 & 1 & 1 & 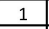 & 1 & 1 & 1 & 1 & 1 & 1 & 1 \\
\hline WATER & $\mathrm{D}$ & 1 & 1 & 1 & 1 & 1 & 1 & 1 & 1 & 1 & 1 & 1 & 1 & 1 & 1 & 1 & 1 & 1 & 1 & 1 & 1 & & 1 & 1 & 1 & 1 & 1 & 1 & 1 \\
\hline CHECK INDUCER & $\mathrm{D} 2$ & 8.8 & 3.1 & 3.3 & 2.1 & 2.0 & \begin{tabular}{|l|}
0.5 \\
\end{tabular} & 3.6 & 2.0 & 1.0 & 1.5 & 1.3 & 3.1 & 0.7 & 0.7 & 0.7 & 0.2 & 1.6 & 135 & 0.7 & 0.6 & 0.9 & 1.0 & 1.2 & 0.9 & 4.0 & 0.7 & 1.3 & 1.0 \\
\hline CHECK INDUCER & D33 & 0.7 & 0.8 & 2.1 & 1.2 & 1.6 & \begin{tabular}{|l|}
4.7 \\
\end{tabular} & 1.7 & 0.8 & 0.9 & 0.5 & \begin{tabular}{|l|}
0.9 \\
\end{tabular} & 3.1 & 0.3 & 0.7 & 1.9 & 0.4 & 1.3 & 8 & 0.6 & 1.9 & 0.7 & 1.3 & \begin{tabular}{|l|}
0.9 \\
\end{tabular} & 0.6 & 1.4 & 0.7 & 4 & 1.1 \\
\hline Lysate 1 & $\mathrm{D} 2$ & 10.8 & 1.0 & 5.4 & 2.5 & 2.1 & \begin{tabular}{|l|}
1.1 \\
\end{tabular} & \begin{tabular}{|l|}
0.8 \\
\end{tabular} & 0.7 & 0.5 & 0.5 & \begin{tabular}{|l|}
0.6 \\
\end{tabular} & 1.0 & 0.7 & 0.8 & 18.0 & 0.4 & 0.8 & .5 & 0.6 & 0.9 & 0.7 & 0.9 & 1.4 & .0 & 0.9 & 6 & .4 & 0.5 \\
\hline Lysate & D3 & 0.9 & 0.4 & 1.0 & 0.8 & 1.3 & \begin{tabular}{|l|}
2.0 \\
\end{tabular} & 0.2 & 0.6 & 0.8 & 0.4 & \begin{tabular}{|l|}
0.6 \\
\end{tabular} & \begin{tabular}{|l|}
0.5 \\
\end{tabular} & 8 & 0.8 & \begin{tabular}{|l|}
0.5 \\
\end{tabular} & & 1.0 & 0.3 & 1.2 & 1.3 & 9 & 0.8 & 0.7 & 0.4 & 0.5 & 1 & 5 & 1.1 \\
\hline Lysate & $\mathrm{D} 2$ & 3.1 & 0.3 & 2.9 & 2.3 & 1.1 & 1.6 & 0.6 & 0.4 & 0.9 & 1.4 & 1.6 & 0.4 & 0.6 & 0.6 & 1.8 & 0.7 & 0.8 & 5.0 & 0.8 & 0.9 & \begin{tabular}{|l|}
0.9 \\
\end{tabular} & 1.0 & 1.1 & 0.6 & 1.0 & 1.0 & 0.5 & 0.7 \\
\hline Lysate $3 \mathrm{~g} / \mathrm{L}$ & D3 & 7.5 & 4.3 & 3.9 & 2.3 & 1.5 & \begin{tabular}{|l|}
2.2 \\
\end{tabular} & 2.5 & 1.7 & 0.6 & 0.5 & \begin{tabular}{|l|}
0.4 \\
\end{tabular} & 2.6 & 0.6 & 0.8 & \begin{tabular}{|l|}
2.8 \\
\end{tabular} & 0.8 & 1.2 & 1.0 & 1.4 & 1.6 & \begin{tabular}{|l|l|}
0.8 \\
\end{tabular} & 1.1 & 1.5 & 2.0 & 1.9 & 0.9 & 1.1 & 0.9 \\
\hline
\end{tabular}

(a)

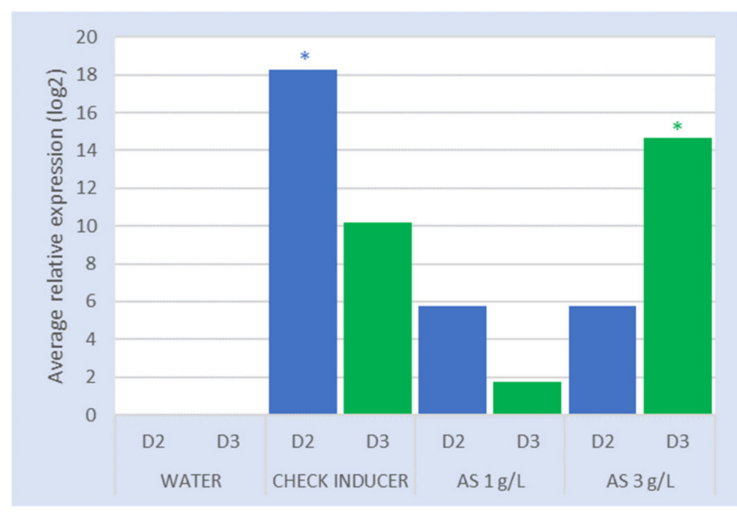

(b)

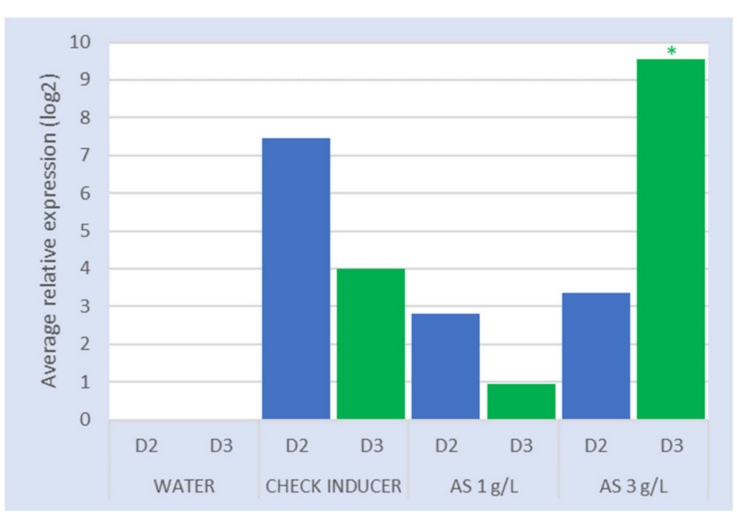

(c)

Figure 1. Elicitor effect of the active substance (AS): (a) Fold change represents relative gene expression values $(2-\Delta \Delta \mathrm{Ct})$ of the defense genes $\left(\mathrm{qPFD}^{\circledR}\right)$ in grapevine, compared to the water control. Values superior or equal to 2 are in green (moderate inductions), and the ten highest values of the lysate data are in red (high inductions). Assessment of the candidate product at two doses, compared to the internal check inducer, at two (D2) and three (D3) days after treatment (D0). $\mathrm{A} \mathrm{H}_{2} \mathrm{O}_{2}$ application was performed $24 \mathrm{~h}$ later (D1) in order to mimic a pathogen attack. The average relative expressions were obtained by RT-qPCR from two independent repetitions and relative to the water control at each sampling date. The results are the average of the relative expressions of genes from two independent repetitions. SA, salicylic acid; JA, jasmonic acid; ET, ethylene. Complete gene names are provided in Table 1. (b) The cumulation of inductions ( $\log 2$ relative expressions $>0$ ) of the 28 defense genes in the grapevine $\mathrm{qPFD}^{\circledR}$, for amoeba lysate compared to the internal check inducer, at the sampling dates D2 and D3. The sum of inductions represents that the sum of the average relative expressions $(\log 2(2-\Delta \Delta \mathrm{Ct}))$ is higher than zero for the 28 genes, relative to the water control, at each sampling date. (c) Cumulation of inductions ( $\log 2$ relative expressions $>0$ ) of the pathogen-related (PR) protein genes from the grapevine $\mathrm{qPFD}^{\circledR}$, for amoeba lysate compared to the internal check inducer, at the sampling dates D2 and D3. The sum of the inductions represents the sum of the average relative expressions $(\log 2(2-\Delta \Delta \mathrm{Ct}))$ of the PR protein genes with values higher than zero, relative to the water control, at each sampling date. ${ }^{*}: p<0.05$.

In the same way, analysis of the cumulation of inductions of the PR genes showed that the internal check inducer demonstrated a low to moderate induction capacity of these genes, higher at the sampling date D2 than at D3, with values around 7 and 4, respectively (Figure 1c). The amoeba lysate, at a dose of $3 \mathrm{~g} / \mathrm{L}$, had a low induction effect at D2 $(<5)$, lower than the internal check inducer and not significantly different from the water control. At D3, it showed a significant induction effect $(p<0.05)$, higher than 
the internal check inducer on the same date. At a dose of $1 \mathrm{~g} / \mathrm{L}$, it had a low induction effect at D2 $(<5)$ not significantly different from the water control $(p>0.05)$, and did not show any significant induction capacity at D3.

\subsubsection{Fold Change of PR Protein Genes}

The analysis will now focus on the fold change values of the PR protein genes at the sampling dates D2 and D3. Fold change represents the relative gene expression values $(2-\Delta \Delta \mathrm{Ct})$ without $\log 2$ transformation (Figure 1a), compared to the water control and averaged for both repetitions. The internal check inducer showed a moderate induction of most of the PR protein genes, 2 to 9 times higher than the water control, at D2. At D3, its induction capacity decreased: only the PR4 and PR14 genes were induced, 2 and 5 times higher than the water control, respectively (Figure 1a). Amoeba lysate, at a dose of $3 \mathrm{~g} / \mathrm{L}$, showed a better induction capacity of the PR protein genes at D3 compared to D2, with induction levels 2.2 to 7.5 times significantly higher than the water control $(p=0.024)$. At a dose of $1 \mathrm{~g} / \mathrm{L}$, it did not show any significant induction effect on the PR protein genes at D3, except for the PR14 gene, which was 2 times more induced than the water control. At D2, it induced the PR8, PR5, PR4, and PR1 genes, 2 to 11 times higher than the water control (Figure 1a).

\subsection{Anti-Oomycete Activity}

The aim of this study was to screen the efficacy of the active substance (AS) against grape downy mildew (P. viticola) under in vitro and in vivo conditions. For the in vitro study, two criteria were studied, namely, sporocyst release and zoospore germination. A dose response was obtained for the sporocyst release; the percentage of the release ranged from $96 \%$ to $5 \%$ for the studied concentrations from 0.03 to $5 \mathrm{~g} / \mathrm{L}$ (Figure 2a). For zoospore germination, the percentages ranged from $92.5 \%$ to $0 \%$ for concentrations from 0.03 to $5 \mathrm{~g} / \mathrm{L}$, respectively. No germination was observed from $0.3 \mathrm{~g} / \mathrm{L}$ (Figure 2a).

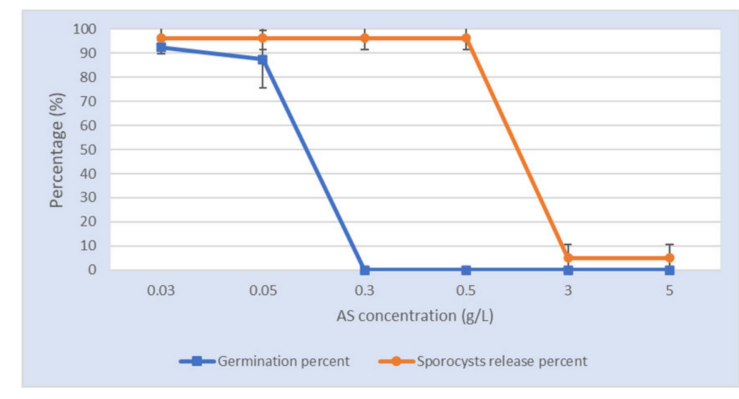

(a)

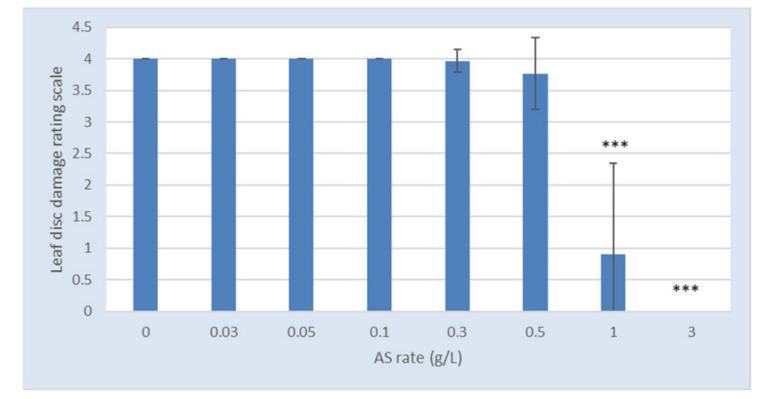

(b)

Figure 2. The direct effect of the active substance (AS). The results are expressed as the mean $+/-$ standard deviation. (a) Evaluation of sporocyst release and zoospore germination in microplates in the presence of increasing doses of AS on P. viticola. The orange line represents the percentage of sporocyst release, while the blue represents the percentage of zoospore germination. The AS concentration ranged from 0.03 to $5 \mathrm{~g} / \mathrm{L}$. (b) Evaluation of the damages caused by P. viticola in the presence of increasing doses of AS on leaf grapevine discs. The AS concentration ranged from 0.03 to $3 \mathrm{~g} / \mathrm{L}$. The leaf disc damage rating scale is an arbitrary scale ranging from 0 (no damage) to 4 (completely damaged). ${ }^{* *}: p<0.001$.

For the in vivo study, three criteria were evaluated, namely, the sporulation of the pathogen mixed with the product, the total number of sporocysts produced, and the contaminating capacity of the sporocysts produced after treatment with the AS. The AS at 1 and $3 \mathrm{~g} / \mathrm{L}$ showed significant control $(p<0.001)$ of the sporulation on leaf discs (Figure $2 b)$, with $77.5 \%$ and $100 \%$ inhibition, respectively. Concerning the production of sporocysts of P. viticola mixed with the AS, for all of the studied rates, except at $3 \mathrm{~g} / \mathrm{L}$, sporocysts were produced, ranging from 246,000 sporocysts at $1 \mathrm{~g} / \mathrm{L}$ to $1,230,000$ sporocysts at $0.03 \mathrm{~g} / \mathrm{L}$. The sporocyst production decreased when the quantity of the AS increased. 
However, whatever the concentration of product applied, the produced sporocysts were able to provide further contamination, except at $3 \mathrm{~g} / \mathrm{L}$, where no sporocysts were produced.

\subsection{Greenhouse Tests}

The goal was to evaluate the sensitivity of $P$. viticola to increasing the doses of a product containing $100 \%$ AS (product code AXP10) under greenhouse conditions. Treatments were applied in a preventive way, $24 \mathrm{~h}$ before contamination with a P. viticola strain sensitive to the main fungicide families used to control grape downy mildew. The level of the disease severity in the untreated control (UTC) was $74.7 \%$, meaning that $74.4 \%$ of the leaf area was affected by disease. A $7.3 \%$ disease severity was observed in the plant treated with the Bordeaux mixture (BM). The disease severity for AXP10-treated plants decreased from $56.7 \%$ to $30.3 \%$ for concentrations 1 and $5 \mathrm{~g} / \mathrm{L}$, respectively (Figure $3 \mathrm{a}$ ). Thus, a clear dose response was observed with a significant protection for the two highest doses $(p=0.043$ and $p=0.0031$, respectively).

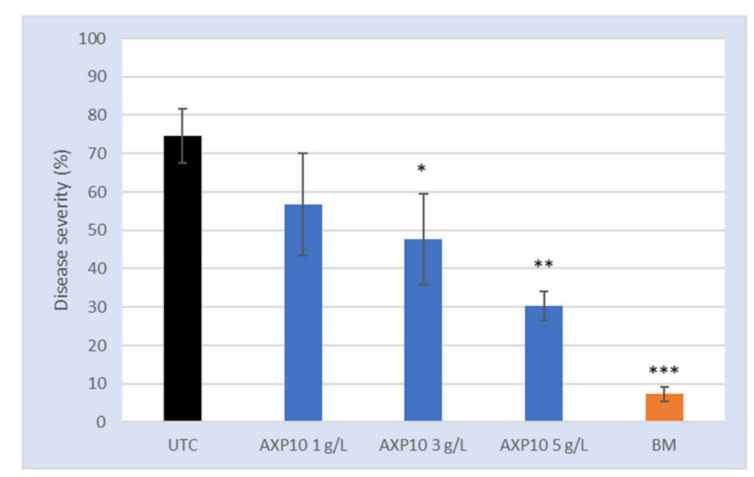

(a)

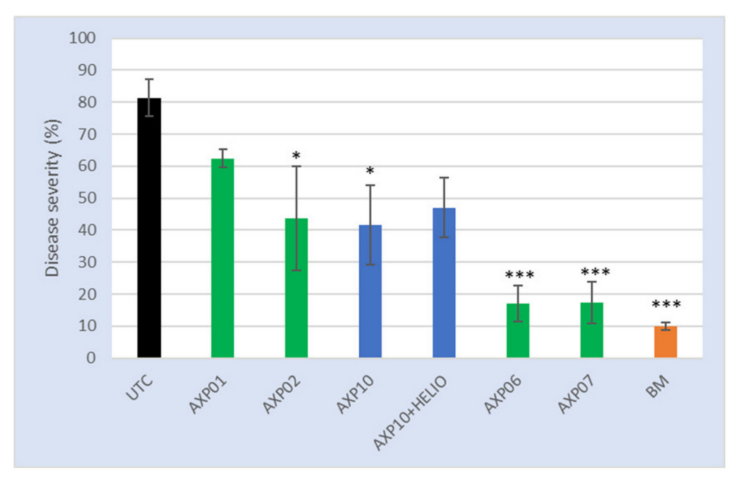

(b)

Figure 3. Greenhouse tests: (a) Disease severity evaluated on leaves L4 to L2 treated with AXP10 at 1,3 , and $5 \mathrm{~g} / \mathrm{L}$, and the Bordeaux mixture (BM) as the reference product. Leaves are numbered from the top of the plant (L1 being the youngest at the top). The untreated control (UTC) was spread with demineralized water. (b) Comparison of the formulated products AXP01, AXP02, AXP06, AXP07, $\mathrm{AXP} 10+\mathrm{HELIOSOL}^{\circledR}$, and pure active substance (AS) AXP10 at a rate of $3 \mathrm{~g} / \mathrm{L}$ of AS. AXP01 and AXP02 contained 50\% AS and were prepared at $6 \mathrm{~g} / \mathrm{L}$, while AXP06 et AX07 contained $62.5 \%$ AS and were prepared at $4.8 \mathrm{~g} / \mathrm{L}$. HELIOSOL ${ }^{\circledR}$ was used at a rate of $1.25 \mathrm{~mL} / \mathrm{L}$, while BM was used at $6.25 \mathrm{~g} / \mathrm{L}$. *: $p<0.05 ;{ }^{* *}: p<0.01 ;{ }^{* * *}: p<0.001$.

The efficacy of the product AXP10 (containing 100\% AS) was compared to the formulated products AXP01, AXP02, AXP06, AXP07, and AXP10 + HELIOSOL ${ }^{\circledR}$ (ACTIONPIN, Castets, France). HELIOSOL ${ }^{\circledR}$ is an eco-adjuvant for plant protection treatments, formulated with pine derivatives; it improves the effectiveness of fungicides, herbicides, insecticides, and growth regulators on all crops. The formulated products were wettable powders. AXP01 and AXP02 contained 50\% AS, and AXP06 and AX07 contained $62.5 \%$ AS. An $81.3 \%$ disease severity was observed in the untreated control, whereas a $10 \%$ disease severity was observed with $3.75 \mathrm{~kg} / \mathrm{ha}$ of BM. AXP06 at $4.8 \mathrm{~g} / \mathrm{L}$ and AXP07 at $4.8 \mathrm{~g} / \mathrm{L} \mathrm{(3} \mathrm{g/L} \mathrm{of} \mathrm{AS)} \mathrm{showed} \mathrm{a} \mathrm{disease} \mathrm{severity} \mathrm{almost} \mathrm{comparable} \mathrm{to} 3.75 \mathrm{~kg} / \mathrm{ha}$ of BM providing a significant protection to the grapevine $(p<0.001)$. AXP02 at $6 \mathrm{~g} / \mathrm{L}(3 \mathrm{~g} / \mathrm{L}$ of AS), AXP10 at $3 \mathrm{~g} / \mathrm{L}$, and AXP10 at $3 \mathrm{~g} / \mathrm{L}$ with $1.25 \mathrm{~mL} / \mathrm{L}$ of HELIOSOL ${ }^{\circledR}$ were comparable (disease severity between $41.7 \%$ and $47 \%$ ), but only AXP02 and AXP10 alone were proven to be statistically different from the untreated control $(p<0.05)$. AXP01 at $6 \mathrm{~g} / \mathrm{L}(3 \mathrm{~g} / \mathrm{L}$ of AS) was by far the least effective treatment, with a disease severity close to $62.3 \%$ (Figure $3 \mathrm{~b}$ ), not significantly different from the untreated control. 


\subsection{Efficacy in the Field}

The first trial was set to confirm the dose response observed in a greenhouse by measuring the reduction in the average disease severity in the treated plants compared to the untreated condition. This was conducted in a field trial performed in 2019 in Hungary (near Gyékényes in the southwest of Hungary). The weather conditions were slightly wet, with one rainy episode from 16th June to 24th June, with a peak at $22 \mathrm{~mm}$ of rain on 22nd June. The last rating was performed on 4 th July and revealed a mildew attack of $4.5 \%$ on the untreated leaves and $21 \%$ on the untreated bunches. The disease was reduced to $2.5 \%, 2.2 \%$, and $2.0 \%$ on the leaves and to $15.1 \%, 13.5 \%$, and $12.5 \%$ on the bunches in the presence of AXP10 at the rate of 500, 1000, and $2000 \mathrm{~g} /$ ha, respectively (Figure 4a,b). A significant protection on the leaves was obtained for the two highest doses of AXP10 $(p<0.05$, Figure $4 b)$ and on the bunches for all the conditions except for the smallest dose of AXP10 (Figure 4a). The level of protection with the highest dose of AXP10 on the bunches was similar to BM RSR Disperss ${ }^{\circledR}$ (UPL Europe Ltd., Warrington, U.K.) containing $200 \mathrm{~g} / \mathrm{kg}$ of copper at $750 \mathrm{~g} / \mathrm{ha} \mathrm{(11.1 \% ).}$

The second trial was set to compare the efficacy of AXP10 at a rate of $0.5,1$, and $2 \mathrm{~kg} / \mathrm{ha}$, in parallel with AXP01 at $2 \mathrm{~kg} / \mathrm{ha}$, equivalent to $1000 \mathrm{~g}$ AS/ha, and with copper oxychloride (Cuprozin ${ }^{\circledR}$ Progress, BIOFA, Germany) against $P$. viticola in a vineyard under natural conditions. This trial was conducted in Germany (located in Sulzfeld in Bavaria) in 2019. Regular episodes of rain were observed throughout the trial, with a probable contaminating event on 20th and 21st May with 16.1 and $11.6 \mathrm{~mm}$ rain, respectively, and again on 11th June with $12.8 \mathrm{~mm}$ of rain. At the end of the experiment, the disease severity under untreated conditions was $19.5 \%$ on the leaves and $14.8 \%$ the on bunches. AXP10 was efficacious at the three tested doses $(500,1000$, and $2000 \mathrm{~g}$ AS/ha) throughout the experiment (from 8th July to 9th August), in decreasing the severity on the leaves and bunches to below $8 \%$, but due to the biological variability, a statistical difference could be measured only for AXP01 at $1 \mathrm{~kg} / \mathrm{ha}$ on the 24 July and for AXP10 at $0.5 \mathrm{~kg} / \mathrm{ha}$ on the 9 August (Figure 4c). The formulated product AXP01 demonstrated a better efficacy, maintaining the severity on the leaves and bunches at below $4 \%$.

The third trial aimed to determine the selectivity and the efficacy of AXP01 at a rate of 1, 2, 4, and $6 \mathrm{~kg} / \mathrm{ha}$ and AXP07 at $3.2 \mathrm{~kg} / \mathrm{ha}$ against $P$. viticola on grapevine. The references were BM RSR Disperss ${ }^{\circledR}$ (UPL Europe Ltd., U.K.) at $3.75 \mathrm{~kg} / \mathrm{ha}$ (750 g copper/ha) and Roméo ${ }^{\circledR}$ (Agrauxine, Marcq en Barouel, France) at $0.25 \mathrm{~kg} / \mathrm{ha}$. Roméo ${ }^{\circledR}$ active substance is composed of $941 \mathrm{~g} / \mathrm{kg}$ of cerevisane (yeast wall extracts of Saccharomyces cerevisiae). This trial was conducted in a vineyard with an artificial infection in Moulon, in the southwest of France. The cold weather in May was not suitable for disease development; however, at the beginning of June and mid-June, heavy contaminating rain occurred, and the disease began to spread in the trial. A new heavy rain was recorded at the beginning of July. The leaves and the bunches were strongly infested in the untreated plots by the end of the trial $(41 \%$ severity on the leaves and $52 \%$ on the bunches). BM at $3.75 \mathrm{~kg} / \mathrm{ha}$ brought about significant leaf and bunch protection, with an efficacy of $80.7 \%$ and $99.6 \%$, respectively. Roméo ${ }^{\circledR}$ at $0.25 \mathrm{~kg} / \mathrm{ha}$ showed no significant reduction in infestation on the leaves $(9 \%$ efficacy, $p>0.05)$ and on the bunches $(22 \%$ efficacy, $p>0.05)$. AXP01 at 1, 2, 4, and $6 \mathrm{~kg} / \mathrm{ha}$ and AXP07 at $3.2 \mathrm{~kg} /$ ha provided comparable results to Roméo ${ }^{\circledR}$ at $0.25 \mathrm{~kg} /$ ha on the leaves (Figure $4 \mathrm{~d}$ ), but the highest dose was significantly different from the control $(p<0.05)$. A better efficacy was obtained on the bunches with a significant protection for the highest dose of AXP01 and for AXP07 ( $p<0.05$, Figure 4e). A dose effect was observed on the bunches for AXP01, with an increased efficacy from $28 \%$ at $500 \mathrm{~g}$ AS/ha to $42 \%$ at $3000 \mathrm{~g} \mathrm{AS} /$ ha (Figure $4 \mathrm{e}$ ). AXP07 at $3.2 \mathrm{~kg} /$ ha provided the best protection on the bunches, with $52 \%$ efficacy (Figure $4 \mathrm{e}$ ). 


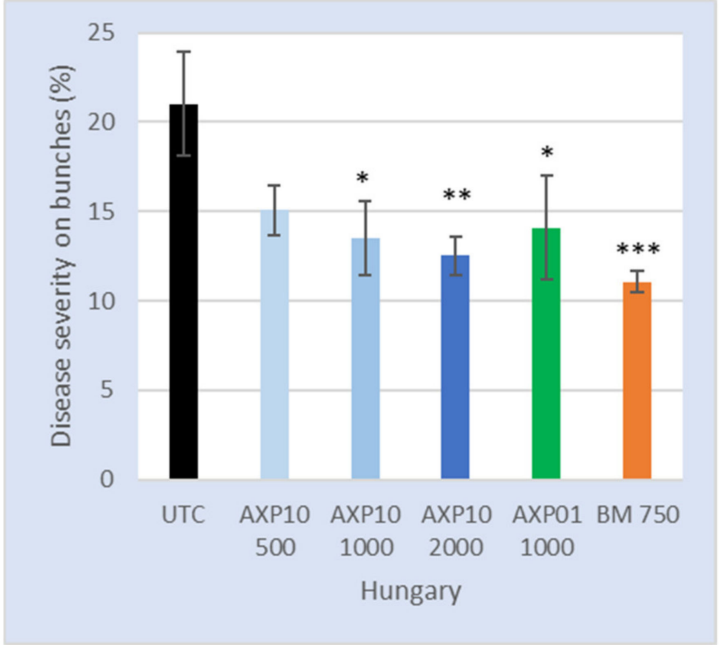

(a)

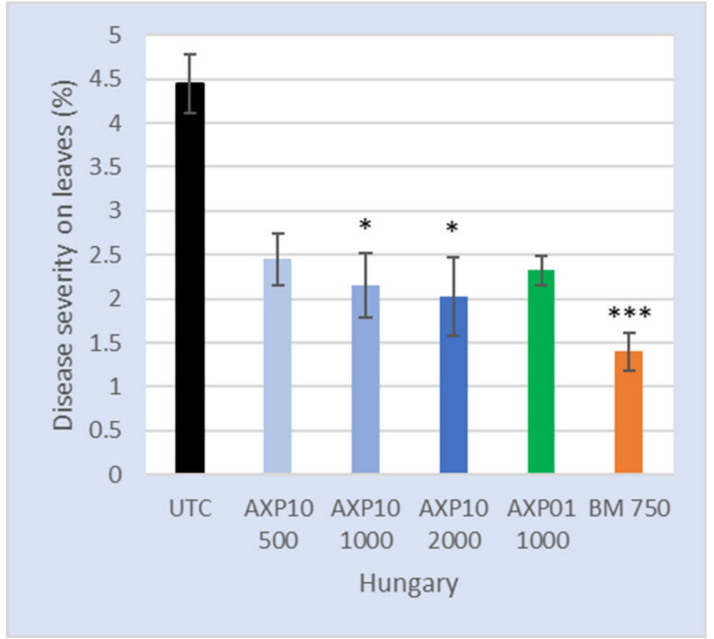

(b)

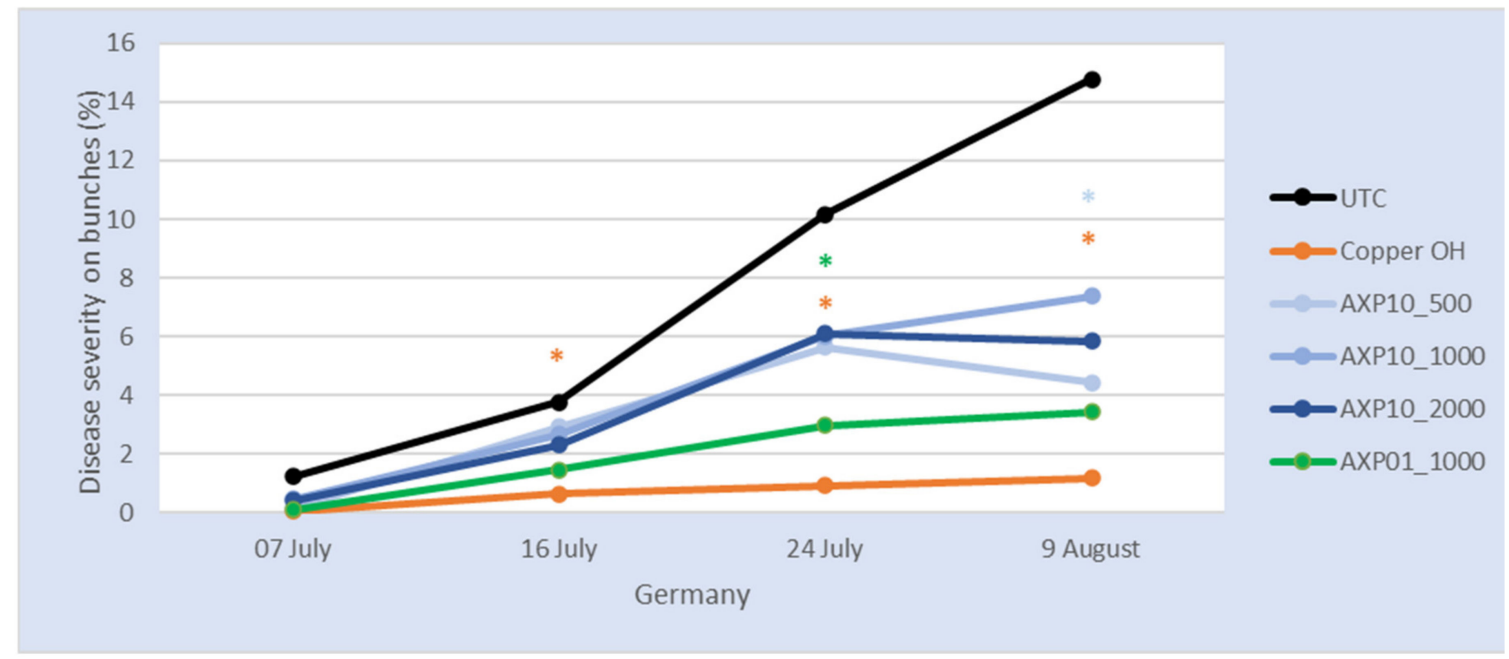

(c)

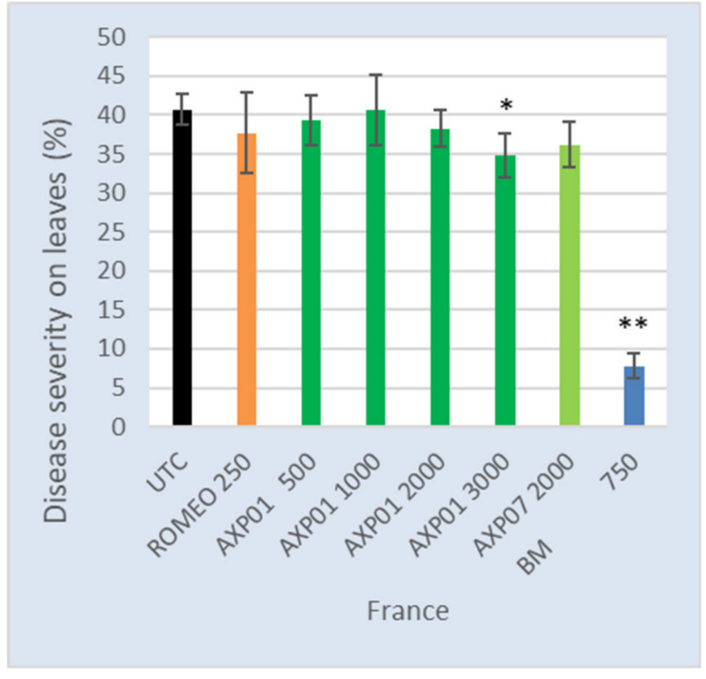

(d)

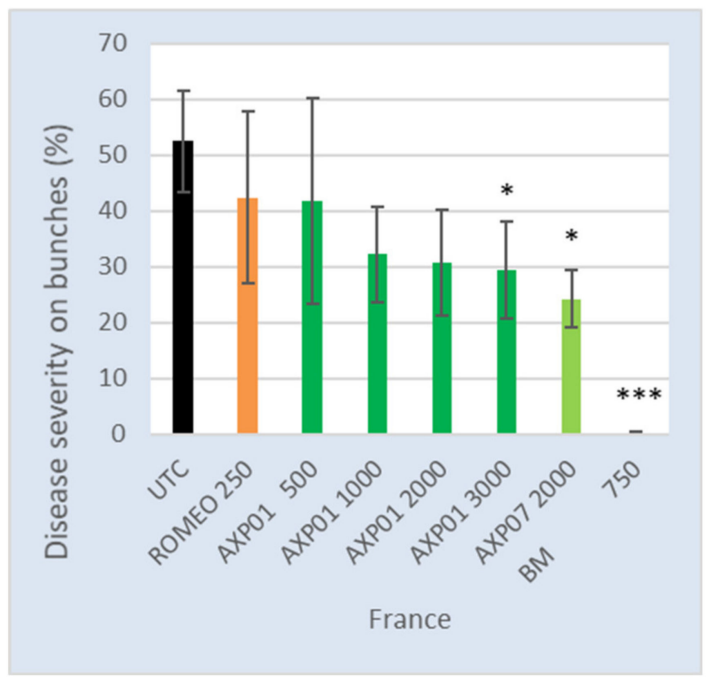

(e)

Figure 4. Field tests: Disease severity evaluated on the leaves (a) and the bunches (b) in a field trial conducted in Hungary. The black represents the untreated control; the increasing color intensities of blue correspond to increasing AXP10 concentrations from 500 to $2000 \mathrm{~g}$ AS/ha; the green represents AXP01 
at $1000 \mathrm{~g} \mathrm{AS} / \mathrm{ha}$; and the orange represents the Bordeaux mixture (BM) at $750 \mathrm{~g}$ copper/ha. (c) Disease severity evaluated on the bunches in a field trial conducted in Germany. The black represents the untreated control; the increasing color intensities of blue correspond to increasing AXP10 concentrations from 500 to $2000 \mathrm{~g}$ AS/ha; the green represents AXP01 at $1000 \mathrm{~g} \mathrm{AS/ha;} \mathrm{and} \mathrm{the} \mathrm{orange}$ represents copper hydroxide at $610 \mathrm{~g}$ copper/ha. Disease severity evaluated on the leaves (d) and the bunches (e) in a field trial conducted in France. The black represents the untreated control; the darker green represents the treatment with AXP01 at concentrations ranging from 500 to $3000 \mathrm{~g} \mathrm{AS} / \mathrm{ha}$; the lighter green represents AXP07 at $2000 \mathrm{~g}$ AS/ha; and the orange represents Roméo ${ }^{\circledR}$ at $250 \mathrm{~g} / \mathrm{ha}$ and the blue represents BM at $750 \mathrm{~g} / \mathrm{ha} .{ }^{*}: p<0.05{ }^{* *}: p<0.01{ }^{* * *}: p<0.001$.

\section{Discussion}

The aim of this study was to evaluate the ability of a natural product to fight grapevine downy mildew. The active substance (AS) of this product is a lysate of the amoeba W. magna C2c Maky manufactured in Amoéba (Chassieu, France). It can stimulate plant natural defenses and also inhibit P. viticola spore germination leading to the protection of the leaves and the bunches of grapevines. The use of W. magna C2c Maky as a fungistatic and fungicide agent is subject to patent protection [20]. Based on the toxicity (Table S1) and ecotoxicity (Table S2) study results, "Lysate of Willaertia magna C2c Maky" is not classified according to European Regulation (EC) No. 1272/2008 on the classification, labeling, and packaging of substances and mixtures, meaning that the product is harmless to both human health and the environment. Actually, despite the toxicity of copper [21] and mancozeb [22], these two compounds are the most commonly used products to protect grapevine against pathogen attacks [4]. Mathematical models have predicted an increase in disease pressure in the future that would lead to an increase in the number of treatment [23]. Meanwhile, there is an increasing demand for the use of products that are harmless for human health and the environment. Biocontrol products are agents and products that use natural mechanisms to fight bio aggressors. The fungicidal biocontrol agents are based on natural substances such as essential oils or microorganisms. A lot of natural compounds and microorganisms are known to have antifungal properties. Among 103 experimental treatments tested under controlled conditions, 32 were further evaluated in field trials in comparison to a copper reference treatment, but none of these substances were able to fully replace copper [7], reinforcing the need for innovation such as our product. Some microorganisms are known to be efficient at fighting grape downy mildew. It can be in their living form, such as Fusarium proliferatum [24,25], Lysobacter capsici AZ78 [26], Bacillus subtilis, and B. pumilus [27], or Trichoderma harzianum T39 [28], for example. Field trials conducted from 1992 to 1995 demonstrated a reduction of disease severity, ranging from $53 \%$ to $99 \%$ depending on the strength of P. viticola attack, by year and on the vine cultivar [24]. Bacillus subtilis GLB191 is also an efficient biological control agent against P. viticola, whose activity results from both a direct effect against the pathogen and the stimulation of plant defenses [29]. The authors managed to identify that the active molecules were surfactin and fengycin, both being lipopeptides. In the same way, Bacillus subtilis KS1 produced iturin A, a lipopeptide active against P. viticola [30]. W. magna C2c Maky is known to possess specific lipopeptides [31] that might be involved in the activity of AS. Further studies are needed to identify the origin of the activity in the lysate of W. magna C2c Maky. To our knowledge, this is the only published use of lysed microbial cells in plant protection domain. Cerevisane contained only the purified cellular walls of Saccharomyces cerevisiae strain LAS117. The Bacillus strains (amyloliquefaciens, firmus, pumilus and thuringiensis) and other microorganisms are sold as living microorganisms. Working with dead cells is a great advantage in term of storage condition and handling facilities because there is no need to maintain viability.

The yeast-derived product cerevisane was also demonstrated to provide protection to grape against downy mildew [32], although the active ingredient is not known. The mode of action of cerevisane was determined by transcriptomic analysis (RNA-Seq). Enzymes involved in hormone metabolism and related plant responses, defense compounds, secondary metabolites, and photosynthetic processes were 
up-regulated [33]. Cerevisane induced more plant defense genes than the lysate of W. magna C2c Maky, but had no direct activity against $P$. viticola, contrary to the lysate of W. magna C2c Maky. In our study, the up-regulated genes were mainly those coding the PR proteins involved in the production of defense compounds, but also the far gene coding the (E, E)-alpha-farnesene synthase, involved in isoprenoid synthesis, having a role in plant defense, and the glutathione S-transferase, involved in the response to oxidative stress. PR proteins are proteins that accumulate in plant tissues in response to abiotic and/or biotic stress or after a plant defense inducer treatment. PR proteins accumulate at a local and systemic level, and their expression demonstrates that plant defense mechanisms have been implemented. They have been classified into 17 families, each one having its own function, more or less known. Most of them have antimicrobial properties through hydrolytic activity on the pathogen cell wall and/or direct toxicity on the pathogen [34]. Under these experimental conditions, W. magna C2c Maky lysate at a dose of $3 \mathrm{~g} / \mathrm{L}$ showed a moderate induction capacity of all of the tested PR protein genes at the sampling date D3. At a dose of $1 \mathrm{~g} / \mathrm{L}, W$. magna C2c Maky lysate induced less PR protein genes (PR1, PR4, PR5, and PR8) and only at the sampling date D2, suggesting that this concentration is too low to efficiently induce plant defenses. In the same way, a dose response and an impact of the day of treatment were also demonstrated in plant defense induction by cerevisane [33]. The best induction with our AS was obtained with the PR1 protein gene. PR1 proteins belong to the most important group of PR proteins induced by a biotic or abiotic stress. They have shown antifungal activity, especially against oomycetes such as Phytophthora infestans on tomato plants [35], and Peronospora species. Their mode of action is related to their sterol-binding activity [36] and suppression of cell death-dependent disease symptoms [37]. PR1 proteins also increase drought tolerance [38], and cerevisane was also shown to induce PR1 proteins [33], as well as COS-OGA (the internal check inducer of this study).

PR2 proteins have a glucanase action ( $\beta-1,3-$ glucanase) and degrade glucan [39], the main compound of bacteria and fungi cell walls. PR2 genes are induced by the salicylic acid pathway [40]. W. magna C2c Maky lysate only induced the synthesis of PR2 proteins at day 3 with the highest concentration tested, whereas COS-OGA produced 3-times more genes encoding PR3 proteins at day 2. Cerevisane also up-regulated these genes [33].

PR4 proteins do not have a well-known characterized function, but have shown ribonuclease and chitinase activity. Studies on wheat have suggested an antifungal activity against Fusarium culmorum [41,42], while other studies have reported antifungal activity on corn [43]. Genes coding PR4 proteins were up-regulated in this study by the AS and by COS-OGA, as well as by treatment with cerevisane [33], suggesting that the genes coding PR4 proteins are very sensitive to all types of foreign compounds.

PR5 proteins, also called thaumatin-like proteins (TLPs), are known to have antifungal and anti-oomycete activity, although the mechanisms by which TLPs exert these activities remain unclear. Several antifungal modes of action have been described, such as membrane permeabilization, $\beta$-glucan degradation or inhibition of enzymes such as xylanases [44]. Their genes were up-regulated by Cerevisane [33], COS-OGA, and W. magna C2c Maky lysate.

PR14 proteins are expressed in young leaves and are involved in lipid transfer. They seem to play a role in the transport of cutin monomers: they contribute to cutin and wax assembly [34]. They have antimicrobial properties, for example, against Pseudomonas, Fusarium, Pythium, and Botrytis [45]. Genes encoding PR14 proteins were induced by COS-OGA and our AS, as well as by cerevisane [33].

Finally, PR15 proteins have oxalate-oxidase activity with known antifungal activity, especially through the plasma membrane degradation of pathogenic fungi, thanks to a wide panel of enzymes [46].

In addition to these plant inducer effects, W. magna C2c Maky lysate demonstrated direct activity on $P$. viticola, with inhibition of both sporocyst release and zoospore germination. This direct effect was not observed with cerevisane [33] or T. harzianum [47]. A plant extract was shown to have both activities by activating plant defense responses and by inhibiting the release and motility of $P$. viticola zoospores [48]. This plant extract needed to be used at $5 \mathrm{~g} / \mathrm{L}$ to reduce $P$. viticola sporulation under greenhouse conditions by $70 \%$; however, the efficacy of the product was not demonstrated in the field 
tests. W. magna $\mathrm{C} 2 \mathrm{c}$ Maky lysate was able to totally inhibit $P$. viticola sporulation in vitro at $0.3 \mathrm{~g} / \mathrm{L}$ (Figure 2a). At $5 \mathrm{~g} / \mathrm{L}$, on plants in a greenhouse, it was able to decrease the severity of mildew attack by $60 \%$ (Figure $3 \mathrm{a}$ ) when $75 \%$ of the leaves were attacked. The efficacy of the raw substance was also proven in the field tests, where an efficacy of $55 \%$ on the leaves and $41 \%$ on the bunches was observed (Figure 4a), similar to the Bordeaux mixture efficiency at $68 \%$ and $47 \%$, respectively. Fields treated with natural substances showed reduced efficacy compared to copper with this level of mildew attack [49], confirming the potential to use the lysate of $W$. magna $C 2 c$ Maky against $P$. viticola. Field trials conducted in 1995, 1997, and 1998 in Israel with $\beta$-aminobutyric acid (BABA), a natural compound, managed to effectively control grape downy mildew $(>90 \%)$ when associated with a reduced dose of chemical fungicides [50]. This compound is present in numerous plants and is a pure elicitor, with no direct effect on fungi [51]. Its prohibitive price (about $7200 € / \mathrm{kg}$; Sigma-Aldrich) could explain why BABA is not authorized in the European Union. However, using raw substances in fields is not a common practice; formulated products are generally used to face environmental conditions detrimental to product efficacy, such as rain events, or to have a better handling and application of products on leaf surfaces [52]. For that purpose, we developed several formulations that were firstly tested and validated in a greenhouse (Figure 3b). Two of them were further assessed in field trials (Figure 4). The AXP01 product was tested in three field trials. In Hungary, its efficacy was similar to the AS at the same concentration (Figure 4a,b), but it provided an increased efficacy in the German trial, with 71\% and $77 \%$ efficacy on the leaves and bunches, respectively (Figure 4c). It was compared to the second formulation, AXP07, in the trial conducted in France. No difference was observed on the leaves, as none of the products were efficient in this case, even the biocontrol reference Roméo ${ }^{\circledR}$ (Figure $4 \mathrm{~d}$ ). AXP07 had a tendency to be more efficient than AXP01 (although not significantly) on the bunches, with 53\% efficacy, whereas AXP01 at the same dose demonstrated $40 \%$ efficacy (Figure 4e). These two formulations will be improved in the coming years. To improve the use of the product and avoid the formation of a dust cloud during the solubilization process, a soluble concentrate and an oil dispersible form are under study.

To conclude, for the first time, a biocontrol product to fight downy mildew of grapevine was developed from a free-living amoeba. W. magna C2c Maky lysate has the rare property to possess a dual mode of action-it is a plant elicitor (indirect effect) and it inhibits the zoospore release and spore germination of $P$. viticola (direct effect). This dual mechanism is a real asset, a guarantee of reliability. Moreover, it is a safe product for human life and the environment, while some natural anti downy mildew fungicides already on the market (like sweet orange essential oil for instance) do have some toxicity and ecotoxicity weaknesses. Finally, the efficacy of the lysate of amoeba was proven to be significantly different from the untreated control in vitro, in planta, and most importantly in fields. Further studies will be conducted to determine the other target pathogens of this natural and safe product, and to position it at its best—in a practical treatment program against grapevines downy mildew.

\section{Materials and Methods}

\subsection{Active Substance and Formulation Preparation}

Willaertia magna C2c Maky (ATCC PTA-7824) was axenically grown at $40{ }^{\circ} \mathrm{C}$ in a $500 \mathrm{~L}$ bioreactor (GE Healthcare, La Rochelle, France) filled with a Chang medium [53] without fetal calf serum. The cells were washed with $\mathrm{NaCl} 0.45 \%$, then lysed by high-pressure homogenization at 20,000 psi (Microfluidics ${ }^{\mathrm{TM}}$, Westwood, MA, USA) and further dehydrated by lyophilization (Eurolyo, Chartres, France). The resulting powder was the raw AS. The plant protection product containing $100 \%$ AS was named AXP10. Two wettable powders (WPs) containing 50\% AS were prepared from AXP10 by SBM Formulation (Bézier, France) and named AXP01 and AXP02. Two other formulated WPs were prepared from the liquid lysate and air-dried by CREATHES (Héricourt, France) to provide AXP06 and AXP07, containing $62.5 \%$ AS. 


\subsection{Study of the Stimulation of Plant Defense Genes by $q P F D^{\circledR}$}

\subsubsection{Biological Material}

Grapevine plants were obtained from the seeds of the Cabernet Sauvignon grape variety by Vegepolys Valley Centre R\&D (Angers, France). They were maintained for 5 weeks in a growth chamber $\left(25^{\circ} \mathrm{C}, 16 \mathrm{~h}\right.$ photoperiod), then selected at the 4-6 leaf stage and transferred to a growth chamber dedicated to the experimentation. Four modalities were tested: the W. magna C2c Maky lysate was tested at 1 and $3 \mathrm{~g} / \mathrm{L}$ and compared to a positive control, COS-OGA [19] at $8.54 \mathrm{~mL} / \mathrm{L}$, a negative control, and the untreated control with water.

\subsubsection{Plant Treatment and Samplings}

Experiments were performed by Vegepolys Valley Centre R\&D under controlled conditions $\left(21{ }^{\circ} \mathrm{C}\right.$ day/18 ${ }^{\circ} \mathrm{C}$ night, $16 \mathrm{~h}$ photoperiod, $70 \%$ humidity) on grapevine plants (4-6 leaf stage). The experimental design was made of blocks of 8 plants for each modality (i.e., amoeba lysate, internal check inducer, and water control). Each modality was sprayed at day 0 (D0). At day 1 (D1), hydrogen peroxide $\left(\mathrm{H}_{2} \mathrm{O}_{2}\right)$ was applied to each modality to mimic a pathogen attack. All treatments were carried out on both leaf surfaces, before run-off, with a compressed air sprayer.

For each modality, 8 foliar discs ( $6 \mathrm{~mm}$ diameter) were sampled by pooling 4 expanded leaves from the leaf in position three (L3) from 4 different plants at:

- D0: Initial sampling before any treatment;

- $\quad$ D2 and D3: Samplings performed 2 and 3 days after treatment.

Samples were deep-frozen in liquid nitrogen, and then stored at $-80{ }^{\circ} \mathrm{C}$ until use. For each treatment, a backup sampling was performed and stored at $-80^{\circ} \mathrm{C}$. Two independent biological repetitions were performed for the whole experiment: from sowing, treatments, up to real-time polymerase chain reaction (RT-PCR) analyses.

\subsubsection{Marker Genes}

Gene expression analysis in the grapevine plantlets was performed by Vegepolys Valley Centre $R \& D$ using the quantitative RT-PCR microplate/DNA chip low density ( PFD $^{\circledR}$ ) method $[18,54]$. Briefly, after RNA extraction of the leaf samples, the yield and quality of the extracted RNA were assessed with a spectrophotometer (Nanodrop ND-1000). RNAs were then retro-transcribed into CDNA and the expression levels of 28 defense genes (Table 1 ) were quantified in triplicate by RT-PCR (SYBR Green) with the $\mathrm{qPFD}^{\circledR}$ tool [18]. The gene expression levels were calculated using the $2-\Delta \Delta \mathrm{Ct}$ method, i.e., relative to a calibrator (i.e., the untreated D0 sample), and normalized by the geometric mean of the relative expressions of 3 reference genes (i.e., $t u A$, actin, and GAPDH) [18]. A log2 transformation of the data was applied in order to provide the same weight to the induction and repression of the genes. The water control plants sampled the same day were analyzed and used as a reference to determine the relative expression. 
Table 1. List of the plant defense genes studied [18].

\begin{tabular}{|c|c|c|c|}
\hline \multicolumn{2}{|c|}{ Defence Classes and Subclasses } & \multicolumn{2}{|r|}{ Defence Genes } \\
\hline Detetile chaso & 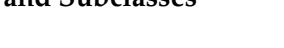 & Gene Codes & Complete Names \\
\hline \multirow{22}{*}{$\begin{array}{l}\text { Chemical and/or } \\
\text { physical barriers }\end{array}$} & \multirow{7}{*}{ PR proteins } & PR-1 & Pathogenesis-related protein 1 \\
\hline & & PR-2 & Pathogenesis-related protein 2 (glucanases) \\
\hline & & PR-4 & Pathogenesis-related protein 4 (hevein-like) \\
\hline & & PR-5 & Pathogenesis-related protein 5 (thaumatin-like, osmotin) \\
\hline & & PR-8 & Pathogenesis-related protein 8 (class III chitinase) \\
\hline & & PR-14 & Pathogenesis-related protein 14 (lipid transfer protein) \\
\hline & & PR-15 & Pathogenesis-related protein 15 (oxalate oxidase) \\
\hline & \multirow{5}{*}{ Phenylpropanoids } & PAL & Phenylalanine ammonia-lyase \\
\hline & & CHS & Chalcone synthase \\
\hline & & DFR & Dihydroflavonol reductase \\
\hline & & ANS & Anthocyanidin synthase \\
\hline & & $\mathrm{PPO}$ & Polyphenol oxidase \\
\hline & \multirow{3}{*}{ Isoprenoids } & HMGR & Hydroxymethyl glutarate-CoA reductase \\
\hline & & FPPS & Farnesyl pyrophosphate synthase \\
\hline & & Far & $(\mathrm{E}, \mathrm{E})$-alpha-farnesene synthase \\
\hline & \multirow[t]{2}{*}{ Cysteines } & CSL & Alliinase \\
\hline & & APOX & Ascorbate peroxidase \\
\hline & \multirow{3}{*}{ Oxidative stress } & GST & Glutathion S-transférase \\
\hline & & POX & Peroxidase \\
\hline & & CalS & Callose synthase \\
\hline & \multirow[t]{2}{*}{ Parietal modification } & Pect & Pectin methyl esterase \\
\hline & & CAD & Cinnamyl alcohol dehydrogenase \\
\hline \multirow{6}{*}{ Hormonal signaling } & \multirow{2}{*}{ Salicylic acid (SA) } & EDS1 & Disease resistance protein EDS 1 \\
\hline & & WRKY & WRKY transcription factor 30 \\
\hline & \multirow{2}{*}{ Jasmonic acid (JA) } & LOX2 & Lipoxygenase AtLOX2 \\
\hline & & JAR & Jasmonate resistant 1 \\
\hline & \multirow{2}{*}{ Ethylene (ET) } & $\mathrm{ACCO}$ & 1-aminocyclopropene-1-carboxylate oxidase \\
\hline & & EIN3 & EIN3-BINDING F BOX PROTEIN 1 \\
\hline
\end{tabular}

\subsection{Anti-Oomycetal Properties of the AS}

These assays were performed by the STAPHYT-L\&G team (Laboratory and Glasshouse, Martillac, France).

\subsubsection{Oomycete Strain}

The oomycete material consisted of a mono-sporocyst strain of downy mildew, from an internal collection created and maintained by STAPHYT-L\&G. It has a normal sensitivity to the main families of fungicides used to control grape downy mildew. As part of this program, preliminary steps were performed to replicate and multiply this strain in order to produce sufficient oomycete material for testing.

\subsubsection{Active Substance Preparation}

A stock solution at $10 \mathrm{~g} / \mathrm{L}$ was prepared, and serial dilutions were carried out with demineralized water by using an automatic dilutor (Miniprep 60, Tecan, Männedorf, Switzerland). Eight concentrations were studied: $0.03,0.05,0.1,0.3,0.5,1,3$, and $5 \mathrm{~g} / \mathrm{L}$. The control condition was performed with demineralized water. Each condition was repeated five times.

\subsubsection{In Vitro Test}

The microplates were inoculated with the spore suspension mixed with the different studied doses. Fresh sporangia were harvested from contaminated leaves with a paint brush and suspended in demineralized water. The concentration of the inoculum was adjusted to $10^{5}$ non-granulated sporangia per milliliter. This sporocyst suspension was thereafter half-diluted by mixing it with an equal volume of two-fold concentrated AS solutions. Once inoculated, the microplates were incubated in an air-conditioned chamber for $6 \mathrm{~h}$. After this time, the development of the spores was 
blocked by an amendment of a $10 \mu \mathrm{L}$ drop of cotton blue. The microplates were then stored in a cool place until they were rated. An evaluation of the percentage of the sporocyst release and the zoospore germination percentage was performed on each of the 5 wells per AS concentration. The assessment was made on 100 sporocysts or zoospores per well. Each well received a percentage score, and an average of the 5 wells was then calculated, giving the percentage of release and the percentage of germination.

\subsubsection{In Vivo Test}

The plant variety used for the tests was that of Cabernet Sauvignon. The plants from which the leaves were taken were produced in a greenhouse under conditions that ensured that the quality of the plants and their health status were controlled throughout the year. Leaf discs with a diameter of $18 \mathrm{~mm}$ were cut using a punch. A two-step process was used to study the efficacy of the AS on leaf discs.

- Evaluation of the disease development on leaf discs

Ten discs were placed into $90 \mathrm{~mm}$ diameter Petri dishes (per condition). Three $10 \mu \mathrm{L}$ droplets of the AS and the sporocyst mixture were deposited on the abaxial (lower) surface of each leaf disc. After inoculation, the Petri dishes were placed into a climatic chamber $\left(21 \pm 2{ }^{\circ} \mathrm{C}, 14 / 10 \mathrm{~h}\right.$ light/darkness period) for 8 days. The moisture necessary for the development of infection was supplied inside the dishes by a wet filter paper. The downy mildew damage on the leaf discs was assessed after the incubation period.

- Evaluation of the contamination properties of spores produced on leaf discs

After the assessment, the spores on each of the contaminated leaf discs were suspended in demineralized water. This suspension was quantified and then used to inoculate new Cabernet Sauvignon leaf discs to evaluate the contaminating potential of the spores that were produced on leaves treated with the AS. A control was inoculated with the spores produced on the untreated leaf discs. Once contaminated, the Petri dishes containing the leaf discs were placed into a climatic chamber $\left(21 \pm 2{ }^{\circ} \mathrm{C}, 14 / 10 \mathrm{~h} \mathrm{light} /\right.$ darkness period) for 8 days. At the end of this incubation period, the downy mildew damage assessment on the leaf discs was recorded. The results of the sporulation scores were analyzed to calculate the efficacy for each concentration studied. An average of the disease severity was calculated from the results obtained from the 10 discs.

Each drop impact deposited on the leaf discs was scored with an average damage score, ranging from 0 to 4, taking into account the surface colonized by the oomycete and the intensity of sporulation with 0 corresponding to the absence of mildew development, 1 to low contamination, 2 to moderate contamination, 3 to high contamination, and 4 to full surface contamination. On each leaf disc, 3 droplets were deposited; thus, 3 scores per leaf were obtained. Finally, for a given concentration, 30 scores were obtained to characterize the efficacy. The efficacy of each rate was obtained by applying the following formula:

$$
E=\frac{(T-D)}{T} \times 100
$$

where $T$ is the average disease severity on the 10 control discs, and $D$ is that observed on the discs treated with the fungicide at different doses.

\subsection{Greenhouse Tests}

\subsubsection{Plant Material}

The trials were carried out on young Cabernet Sauvignon plants produced in a greenhouse (STAPHYT-L\&G) from one-eyed shoots. These plants were grown in a greenhouse under conditions that ensured the control of the quality of the plants and their health status during their cultivation. Homogeneous batches of 6 plants were formed for the study of each modality of the test. Each plant was staked, just before the application of the treatment, and the leaf stages were identified using a colored 
marker placed under the third leaf spread. This later allowed, during the assessment, an identification of the treated and untreated leaves. At the end of the rating, an analysis of the results was carried out on the 5 plants constituting the most homogeneous batch (the least significant variation around the average of the symptoms).

\subsubsection{AS Application}

According to the experimental design, the application mode comprised the spraying of the AS on the whole plant. Both the upper and lower surfaces of the leaves were treated. The spraying was performed in a preventive manner, $24 \mathrm{~h}$ before infection. A classical application method by spraying was used: The plants were placed in a spray booth equipped with a spray bench carrying 5 nozzles (2 lateral right, 2 lateral left, and 1 upper). This bench moved on a guidance rail at a constant speed. The pressure at which spraying was applied and the speed of the bench were a function of the volume to be supplied. In this study, the volume of water used was $600 \mathrm{~L} / \mathrm{ha}$. The different solutions tested were AXP10 at 1, 3, and $5 \mathrm{~g} / \mathrm{L}$ compared to the Bordeaux mixture (RSR Disperss) at $6.25 \mathrm{~g} / \mathrm{L}$ in the first trial. A second trial was performed to compare the AS AXP10 with several formulations with $3 \mathrm{~g} / \mathrm{L}$ of AS. AXP01 and AXP02 contained 50\% AS and were thus sprayed at $6 \mathrm{~g} / \mathrm{L}$, while AXP06 and AXP07 contained $62.5 \%$ AS and were thus sprayed at $4.8 \mathrm{~g} / \mathrm{L}$. AXP10 at $3 \mathrm{~g} / \mathrm{L}$ was also tested in combination with HELIOSOL ${ }^{\circledR}$ (ActionPin, Castets, France) at $1.25 \mathrm{~mL} / \mathrm{L}$.

\subsubsection{Plasmopara viticola Inoculation}

The fungal material consisted of a mono-sporocyst strain of downy mildew from an internal collection created and maintained by STAPHYT-L\&G. It has normal sensitivity to the main families of fungicides used to control grape downy mildew. A suspension of sporocysts was prepared by washing the infected leaves with demineralized water at a low temperature in order to block the release of zoospores. The spores of the fungus were thus harvested and then titrated with a Malassez cell. The optimal concentration was 25,000 spores $/ \mathrm{mL}$. The plants were inoculated by spraying a sporangial suspension on the lower surface of the leaves. Each plant was treated separately and was contaminated on each leaf stage.

\subsubsection{Incubation and Notations}

After their contamination, the 6 plants of the same condition were gathered inside a hermetic enclosure in order to maintain a saturated relative humidity, necessary for the development of the disease. This device also made it possible to isolate the different test conditions from one another. The isolated plant batches were placed in an air-conditioned room $\left(21 \pm 2{ }^{\circ} \mathrm{C}, 14 \mathrm{~h}\right.$ of light). A few hours after inoculation $(\sim 8 \mathrm{~h})$, the incubation chambers were removed. The plants remained in incubation for 7 days under the same light and temperature conditions as before. At the end of this period, the incubation chambers were replaced for each condition to allow the expression of the pathogen's sporulation, and $24 \mathrm{~h}$ after the replacement of the enclosures, an estimate of the severity of the disease was established for each plant and for each leaf stage (from L4 to L1 $+\mathrm{N}, \mathrm{N}$ being the new non treated leaves that appeared during the 7 days of incubation).

The assessment was based on visual observations of the fungus damage, by considering two parameters: the foliar surface colonized by the fungus and the intensity of sporulation. We used a scale from $0 \%$ to $100 \%$ (with an increase of $5 \%$ by $5 \%$ ). Each leaf was observed individually. For each plant, the disease severity was calculated, only taking into account the score assigned for the leaves L2, L3, and L4. The leaves were numbered before the treatment with L1 which was the most recent leaf at the top of the plant. Then, for each condition of the test, a mean disease severity score was calculated by averaging the attack rates obtained for the 5 plants of the same condition (elimination of the plant with the disease severity furthest from the average disease severity). From this mean disease severity 
score, the efficacy $(E)$ of the product for each condition could be calculated by comparison to the mean disease severity score obtained in the control condition (untreated plants) according to the formula:

$$
E=\frac{(T-D)}{T} \times 100
$$

where $T$ is the mean disease severity score obtained for the control condition (untreated plants), and $D$ is that observed on the plants treated with the fungicide at different doses.

\subsection{Field Tests}

Three trials were conducted in 2019 to assess the efficacy against downy mildew on grapes of the raw AS, AXP10, and the two formulated products, AXP01 (containing 50\% AS) and AXP07 (containing 62.5\% AS). One efficacy trial was conducted in Hungary, one in Germany, and one in France.

The observations were focused on the incidence and severity of the disease on grapevine bunches and leaves. The trial design, test compound efficacy evaluations, and phytotoxicity assessments were all performed in compliance with the principles of good experimental practices according to the European and Mediterranean Plant Protection Organization (EPPO) guidelines, which define the standard procedures for the evaluation of plant protection products. The application and evaluation dates were expressed according to the Biologische Bundesanstalt, Bundessortenamt and CHemical industry $(\mathrm{BBCH})$ code [55], corresponding to specific developmental stages of the plant. For example, $\mathrm{BBCH} 77$ corresponds to bunch closure and $\mathrm{BBCH} 81$ to the beginning of berry ripening.

\subsubsection{Field Test Conducted in Hungary}

SynTech Research Hungary Ltd. (Szombathely, Hungary) investigated the efficacy of AXP10 at 0.5, 1, and $2 \mathrm{~kg} / \mathrm{ha}$ in comparison to AXP01 at $2 \mathrm{~kg} / \mathrm{ha}$ and to copper (BORDÓMIX DG at $3.75 \mathrm{~kg} / \mathrm{ha}$ ) against downy mildew of grapevine (Plasmopara viticola) near Gyékényes in the southwest of Hungary in $2019(46.258073,16.96484)$. The grapevine variety was Chardonnay, and the age of the plantation was 10 years. The treatments were applied in four replications on small plots. The treatments were applied six times on 6th June 2019 at BBCH 57, on 12th June 2019 at BBCH 60, on 18th June 2019 at BBCH 65, on 23rd June 2019 at BBCH 69, on 28th June 2019 at BBCH 71, and on 3rd July 2019 at BBCH 71 of the crop. As application equipment, an electronic pump backpack sprayer was used with a $500 \mathrm{~L} / \mathrm{ha}$ spray volume. The number of spots caused by downy mildew was counted per plot. The percentage of the severity and the incidence of the disease on the leaves and bunches were also assessed.

\subsubsection{Field Test Conducted in Germany}

Hetterich Fieldwork GbR (Schwarzach am Main, Germany) investigated the efficacy of AXP10 at 0.5, 1, and $2 \mathrm{~kg} / \mathrm{ha}$ in comparison to AXP01 at $2 \mathrm{~kg} / \mathrm{ha}$ and to copper oxychloride (Cuprozin ${ }^{\circledR}$ Progress at 0.4 to $1.6 \mathrm{~L} / \mathrm{ha}$ ) against $P$. viticola under natural conditions in a German vineyard located in Sulzfeld in Bavaria $(49.70766,10.116076)$. The grapevine variety was Müller Turgau. The first application took place on 7th of June at $\mathrm{BBCH} 57$ of the crop. The next applications were performed on 14th June at $\mathrm{BBCH} 65,21$ st June at $\mathrm{BBCH} 69,27$ th June at BBCH 73, 5th July at BBCH 75, 10th July at BBCH 77, 18th July at $\mathrm{BBCH} 79$, and 26th July at $\mathrm{BBCH} 81$. This trial was conducted with an artificial infestation performed on 13th June. The plants were sprayed with a sporal solution. The sprayed leaves were then packed in plastic bags for $12 \mathrm{~h}$. After the $12 \mathrm{~h}$, the bags were removed. The infection worked very well, and the first infestation on the leaves was visible on the 24th of June. The number of spots caused by downy mildew was counted per plot. The percentage of the severity and the incidence of the disease on the leaves and bunches were also assessed. 


\subsubsection{Field Test Conducted in France}

Sciences Agro Atlantique (Saint-Germain-du-Puch, France) investigated the efficacy of AXP01 at $1,2,4$, and $6 \mathrm{~kg} / \mathrm{ha}$ in comparison to AXP07 at $3.2 \mathrm{~kg} / \mathrm{ha}$, to copper (BM RSR Disperss ${ }^{\circledR}$ at $3.75 \mathrm{~g} / \mathrm{ha}$ ), and to a biological control product (Roméo ${ }^{\circledR}$ at $0.25 \mathrm{~kg} / \mathrm{ha}$ ) against $P$. viticola under natural conditions in a French vineyard located in Moulon in the southwest of France $(44.860109,-0.22577)$. The grapevine variety was Merlot. The fungicides were applied every 6 to 8 days from 29th April, at the crop stage of the fifth unfolded leaf, until 9th July at bunch closure, for a total of 11 applications. An artificial infection was produced on a buffer plant on 9th May, 3 days after the second application. Three leaves on the plant buffer stock (not included in the study) between plots were infested with a solution of 60,000 spores/mL of a local environmental P. viticola strain. The number of spots caused by downy mildew was counted per plot. The percentage of the severity and the incidence of the disease on the leaves and bunches were also assessed.

\subsection{Statistical Analyses}

Statistical significance was determined through the use of analysis of variance (ANOVA) (Kruskal-Wallis test and multiple pair-wise comparison Dunn test).

Supplementary Materials: The following are available online at http://www.mdpi.com/2223-7747/9/8/1013/s1: Table S1: Toxicological studies performed to assess the hazard of the active substance "Lysate of Willaertia magna C2c Maky" to human health; Table S2: Ecotoxicological studies performed to assess the hazard of the active substance "Lysate of Willaertia magna C2c Maky" to the environment.

Author Contributions: Conceptualization, S.D., J.-B.E., and J.-L.S.; formal analysis, S.D.; methodology, S.D. and J.-L.S.; project administration, S.D., O.A., J.-B.E., and J.-L.S.; supervision, O.A.; writing-original draft, S.D. and L.M.; writing - review and editing, S.D. All authors have read and agreed to the published version of the manuscript.

Funding: This research received no external funding.

Acknowledgments: The authors are very grateful to Florence Brouard, Antoine Gallorini, and Bertrand Cova for the amoeba lysate production. The authors also thank all of the contract research organizations for their work, and particularly the Staphyt-L\&G team for their strong involvement.

Conflicts of Interest: The authors declare no conflicts of interest. All the authors are employed by Amoéba SA. The company provides financial support for the research of this article, but the funders had no role in the design of the study; in the collection, analyses, or interpretation of data; in the writing of the manuscript; or in the decision to publish the results.

\section{References}

1. The International Organisation of Vine and Wine Current Situation of the Vitivinicultural Sector at a Global Level. Available online: http://www.oiv.int/en/oiv-life/current-situation-of-the-vitivinicultural-sector-at-aglobal-level (accessed on 30 April 2020).

2. Agrios, G.N. Plant diseases caused by fungi. In Plant Pathology, 5th ed.; Agrios, G.N., Ed.; Academic Press: New York, NY, USA, 2005; pp. 385-614.

3. Jermini, M.; Blaise, P.; Gessler, C. Quantitative effect of leaf damage caused by downy mildew (Plasmopara viticola) on growth and yield quality of grapevine'Merlot'(Vitis vinifera). Vitis 2010, 49, 77-85.

4. Gessler, C.; Pertot, I.; Perazzolli, M. Plasmopara viticola: A review of knowledge on downy mildew of grapevine and effective disease management. Phytopathol. Mediterr. 2011, 50, 3-44. [CrossRef]

5. Fröbel, S.; Zyprian, E. Colonization of Different Grapevine Tissues by Plasmopara viticola—A Histological Study. Front. Plant. Sci. 2019, 10, 951. [CrossRef] [PubMed]

6. Negrel, L. Integrated Analysis of the Grapevine Response to Plasmopara viticola Infection: Through Study of Breakdown Resistance. Ph.D. Thesis, Université de Strasbourg, Grand Est, France, 2016.

7. Dagostin, S.; Schärer, H.-J.; Pertot, I.; Tamm, L. Are there alternatives to copper for controlling grapevine downy mildew in organic viticulture? Crop Prot. 2011, 30, 776-788. [CrossRef] 
8. Ambrosini, V.G.; Rosa, D.J.; Corredor Prado, J.P.; Borghezan, M.; Bastos de Melo, G.W.; Fonsêca de Sousa Soares, C.R.; Comin, J.J.; Simão, D.G.; Brunetto, G. Reduction of copper phytotoxicity by liming: A study of the root anatomy of young vines (Vitis labrusca L.). Plant Physiol. Biochem. 2015, 96, 270-280. [CrossRef]

9. European Commission A European Green Deal. Available online: https://ec.europa.eu/info/strategy/ priorities-2019-2024/european-green-deal_en (accessed on 10 August 2020).

10. De Jonckheere, J.F.; Dive, D.G.; Pussard, M.; Vickerman, K. Willaertia magna gen. nov., sp. nov.(Vahlkampfiidae), a thermophilic amoeba found in different habitats. Protistologica 1984, 20, 5-13.

11. Hasni, I.; Chelkha, N.; Baptiste, E.; Mameri, M.R.; Lachuer, J.; Plasson, F.; Colson, P.; La Scola, B. Investigation of potential pathogenicity of Willaertia magna by investigating the transfer of bacteria pathogenicity genes into its genome. Sci. Rep. 2019, 9, 18318. [CrossRef]

12. Hasni, I.; Decloquement, P.; Demanèche, S.; Mameri, R.M.; Abbe, O.; Colson, P.; La Scola, B. Insight into the Lifestyle of Amoeba Willaertia magna during Bioreactor Growth Using Transcriptomics and Proteomics. Microorganisms 2020, 8, 771. [CrossRef]

13. Barbaree, J.M.; Fields, B.S.; Feeley, J.C.; Gorman, G.W.; Martin, W.T. Isolation of protozoa from water associated with a legionellosis outbreak and demonstration of intracellular multiplication of Legionella pneumophila. Appl. Environ. Microbiol. 1986, 51, 422-424. [CrossRef]

14. Scheikl, U.; Sommer, R.; Kirschner, A.; Rameder, A.; Schrammel, B.; Zweimüller, I.; Wesner, W.; Hinker, M.; Walochnik, J. Free-living amoebae (FLA) co-occurring with legionellae in industrial waters. Eur. J. Protistol. 2014, 50, 422-429. [CrossRef]

15. Clarholm, M. Protozoan grazing of bacteria in soil-Impact and importance. Microb. Ecol. 1981, 7, 343-350. [CrossRef] [PubMed]

16. Rodríguez-Zaragoza, S. Ecology of Free-Living Amoebae. Crit. Rev. Microbiol. 1994, 20, 225-241. [CrossRef] [PubMed]

17. Hasni, I.; Jarry, A.; Quelard, B.; Carlino, A.; Eberst, J.-B.; Abbe, O.; Demanèche, S. Intracellular Behaviour of Three Legionella pneumophila Strains within Three Amoeba Strains, Including Willaertia magna C2c Maky. Pathogens 2020, 9, 105. [CrossRef] [PubMed]

18. Brisset, M.-N.; Bernonville, T.D.D. Device for Determining or Studying the State of Stimulation of the Natural Defences of Plants or Portions of Plants. U.S. Patent No. 9,290,788, 22 March 2016.

19. Van Aubel, G.; Buonatesta, R.; Van Cutsem, P. COS-OGA: A novel oligosaccharidic elicitor that protects grapes and cucumbers against powdery mildew. Crop Prot. 2014, 65, 129-137. [CrossRef]

20. Plasson, F.; Mameri, M.O. Therapeutic or Non-Therapeutic Use of Protozoans of the Willaertia Genus as a Fungistatic and/or Fungicide. WO2019030459, 14 February 2019.

21. Flemming, C.A.; Trevors, J.T. Copper toxicity and chemistry in the environment: A review. Water Air Soil Pollut. 1989, 44, 143-158. [CrossRef]

22. Paro, R.; Tiboni, G.M.; Buccione, R.; Rossi, G.; Cellini, V.; Canipari, R.; Cecconi, S. The fungicide mancozeb induces toxic effects on mammalian granulosa cells. Toxicol. Appl. Pharmacol. 2012, 260, 155-161. [CrossRef]

23. Francesca, S.; Simona, G.; Nicola, T.F.; Andrea, R.; Vittorio, R.; Federico, S.; Cynthia, R.; Lodovica, G.M. Downy mildew (Plasmopara viticola) epidemics on grapevine under climate change. Glob. Change Biol. 2006, 12, 1299-1307. [CrossRef]

24. Falk, S.P.; Pearson, R.C.; Gadoury, D.M.; Seem, R.C.; Sztejnberg, A. Fusarium proliferatum as a biocontrol agent against grape downy mildew. Phytopathology 1996, 86, 1010-1017. [CrossRef]

25. Bakshi, S.; Sztejnberg, A.; Yarden, O. Isolation and Characterization of a Cold-Tolerant Strain of Fusarium proliferatum, a Biocontrol Agent of Grape Downy Mildew. Phytopathology ${ }^{\circledR}$ 2001, 91, 1062-1068. [CrossRef]

26. Puopolo, G.; Giovannini, O.; Pertot, I. Lysobacter capsici AZ78 can be combined with copper to effectively control Plasmopara viticola on grapevine. Microbiol. Res. 2014, 169, 633-642. [CrossRef]

27. Zhang, X.; Zhou, Y.; Li, Y.; Fu, X.; Wang, Q. Screening and characterization of endophytic Bacillus for biocontrol of grapevine downy mildew. Crop Prot. 2017, 96, 173-179. [CrossRef]

28. Perazzolli, M.; Dagostin, S.; Ferrari, A.; Elad, Y.; Pertot, I. Induction of systemic resistance against Plasmopara viticola in grapevine by Trichoderma harzianum T39 and benzothiadiazole. Biol. Control 2008, 47, 228-234. [CrossRef] 
29. Li, Y.; Héloir, M.-C.; Zhang, X.; Geissler, M.; Trouvelot, S.; Jacquens, L.; Henkel, M.; Su, X.; Fang, X.; Wang, Q.; et al. Surfactin and fengycin contribute to the protection of a Bacillus subtilis strain against grape downy mildew by both direct effect and defence stimulation. Mol. Plant Pathol. 2019, 20, 1037-1050. [CrossRef] [PubMed]

30. Furuya, S.; Mochizuki, M.; Aoki, Y.; Kobayashi, H.; Takayanagi, T.; Shimizu, M.; Suzuki, S. Isolation and characterization of Bacillus subtilis KS1 for the biocontrol of grapevine fungal diseases. Biocontrol Sci. Technol. 2011, 21, 705-720. [CrossRef]

31. Dey, R. Étude Comparée de la Prolifération de Legionella pneumophila dans Différents Hôtes Amibiens et de Leurs Inter-Relations: Implication Potentielle de Phospholipides Aminés. Ph.D. Thesis, Université Claude Bernard-Lyon I, Villeurbanne, France, 2010.

32. Pujos, P.; Martin, A.; Farabullini, F.; Pizzi, M. Romeo ${ }^{\mathrm{TM}}$, cerevisane-based biofungicide against the main diseases of grape and of other crops: General description. In Proceedings of the Atti, Giornate Fitopatologiche, Chianciano Terme (Siena), Italy, 18-21 March 2014; Volume 2, pp. 51-56.

33. De Miccolis Angelini, R.M.; Rotolo, C.; Gerin, D.; Abate, D.; Pollastro, S.; Faretra, F. Global transcriptome analysis and differentially expressed genes in grapevine after application of the yeast-derived defense inducer cerevisane. Pest Manag. Sci. 2019, 75, 2020-2033. [CrossRef]

34. Sels, J.; Mathys, J.; De Coninck, B.M.A.; Cammue, B.P.A.; De Bolle, M.F.C. Plant pathogenesis-related (PR) proteins: A focus on PR peptides. Plant Physiol. Biochem. 2008, 46, 941-950. [CrossRef]

35. Faino, L.; Carli, P.; Testa, A.; Cristinzio, G.; Frusciante, L.; Ercolano, M.R. Potato R1 resistance gene confers resistance against Phytophthora infestans in transgenic tomato plants. Eur. J. Plant Pathol. 2010, 128, $233-241$. [CrossRef]

36. Gamir, J.; Darwiche, R.; Van't Hof, P.; Choudhary, V.; Stumpe, M.; Schneiter, R.; Mauch, F. The sterol-binding activity of PATHOGENESIS-RELATED PROTEIN 1 reveals the mode of action of an antimicrobial protein. Plant J. 2017, 89, 502-509. [CrossRef]

37. Lincoln, J.E.; Sanchez, J.P.; Zumstein, K.; Gilchrist, D.G. Plant and animal PR1 family members inhibit programmed cell death and suppress bacterial pathogens in plant tissues. Mol. Plant Pathol. 2018, 19, 2111-2123. [CrossRef]

38. Liu, W.-X.; Zhang, F.-C.; Zhang, W.-Z.; Song, L.-F.; Wu, W.-H.; Chen, Y.-F. Arabidopsis Di19 Functions as a Transcription Factor and Modulates PR1, PR2, and PR5 Expression in Response to Drought Stress. Mol. Plant 2013, 6, 1487-1502. [CrossRef]

39. Charles, M.T.; Tano, K.; Asselin, A.; Arul, J. Physiological basis of UV-C induced resistance to Botrytis cinerea in tomato fruit. V. Constitutive defence enzymes and inducible pathogenesis-related proteins. Postharvest Biol. Technol. 2009, 51, 414-424. [CrossRef]

40. Thibaud, M.-C.; Gineste, S.; Nussaume, L.; Robaglia, C. Sucrose increases pathogenesis-related PR-2 gene expression in Arabidopsis thaliana through an SA-dependent but NPR1-independent signaling pathway. Plant Physiol. Biochem. 2004, 42, 81-88. [CrossRef] [PubMed]

41. Caruso, C.; Chilosi, G.; Leonardi, L.; Bertini, L.; Magro, P.; Buonocore, V.; Caporale, C. A basic peroxidase from wheat kernel with antifungal activity. Phytochemistry 2001, 58, 743-750. [CrossRef]

42. Bertini, L.; Caporale, C.; Testa, M.; Proietti, S.; Caruso, C. Structural basis of the antifungal activity of wheat PR4 proteins. FEBS Lett. 2009, 583, 2865-2871. [CrossRef]

43. Bravo, J.M.; Campo, S.; Murillo, I.; Coca, M.; San Segundo, B. Fungus- and wound-induced accumulation of mRNA containing a class II chitinase of the pathogenesis-related protein 4 (PR-4) family of maize. Plant Mol. Biol. 2003, 52, 745-759. [CrossRef]

44. Petre, B.; Major, I.; Rouhier, N.; Duplessis, S. Genome-wide analysis of eukaryote thaumatin-like proteins (TLPs) with an emphasis on poplar. BMC Plant Biol. 2011, 11, 33. [CrossRef]

45. Kido, E.A.; Pandolfi, V.; Houllou-Kido, L.M.; Andrade, P.P.; Marcelino, F.C.; Nepomuceno, A.L.; Abdelnoor, R.V.; Burnquist, W.L.B.; Benko-Iseppon, A.M. Plant Antimicrobial Peptides: An Overview of SuperSAGE Transcriptional Profile and a Functional Review. Available online: http://www.eurekaselect. com/85038/article (accessed on 19 March 2020).

46. Ferreira, R.B.; Monteiro, S.; Freitas, R.; Santos, C.N.; Chen, Z.; Batista, L.M.; Duarte, J.; Borges, A.; Teixeira, A.R. The role of plant defence proteins in fungal pathogenesis. Mol. Plant Pathol. 2007, 8, 677-700. [CrossRef]

47. Perazzolli, M.; Roatti, B.; Bozza, E.; Pertot, I. Trichoderma harzianum T39 induces resistance against downy mildew by priming for defense without costs for grapevine. Biol. Control 2011, 58, 74-82. [CrossRef] 
48. Krzyzaniak, Y.; Trouvelot, S.; Negrel, J.; Cluzet, S.; Valls, J.; Richard, T.; Bougaud, A.; Jacquens, L.; Klinguer, A.; Chiltz, A.; et al. A Plant Extract Acts Both as a Resistance Inducer and an Oomycide Against Grapevine Downy Mildew. Front. Plant. Sci. 2018, 9, 1085. [CrossRef]

49. La Torre, A.; Talocci, S.; Spera, G.; Valori, R. Control of downy mildew on grapes in organic viticulture. Commun. Agric. Appl. Biol. Sci. 2008, 73, 169-178.

50. Reuveni, M.; Zahavi, T.; Cohen, Y. Controlling downy mildew (Plasmopara viticola) in field-grown grapevine with $\beta$-aminobutyric acid (BABA). Phytoparasitica 2001, 29, 125-133. [CrossRef]

51. Thevenet, D.; Pastor, V.; Baccelli, I.; Balmer, A.; Vallat, A.; Neier, R.; Glauser, G.; Mauch-Mani, B. The priming molecule $\beta$-aminobutyric acid is naturally present in plants and is induced by stress. N. Phytol. 2017, 213, 552-559. [CrossRef] [PubMed]

52. Leggett, M.; Leland, J.; Kellar, K.; Epp, B. Formulation of microbial biocontrol agents-An industrial perspective. Can. J. Plant Pathol. 2011, 33, 101-107. [CrossRef]

53. De Jonckheere, J. Use of an axenic medium for differentiation between pathogenic and nonpathogenic Naegleria fowleri isolates. Appl. Environ. Microbiol. 1977, 33, 751-757. [CrossRef] [PubMed]

54. Dugé de Bernonville, T.; Marolleau, B.; Staub, J.; Gaucher, M.; Brisset, M.-N. Using Molecular Tools To Decipher the Complex World of Plant Resistance Inducers: An Apple Case Study. J. Agric. Food Chem. 2014, 62, 11403-11411. [CrossRef]

55. Meier, U.; Bleiholder, H.; Buhr, L.; Feller, C.; Hack, H.; Heß, M.; Lancashire, P.D.; Schnock, U.; Stauß, R.; Van Den Boom, T. The BBCH system to coding the phenological growth stages of plants-history and publications. J. Kulturpflanzen 2009, 61, 41-52.

(C) 2020 by the authors. Licensee MDPI, Basel, Switzerland. This article is an open access article distributed under the terms and conditions of the Creative Commons Attribution (CC BY) license (http://creativecommons.org/licenses/by/4.0/). 